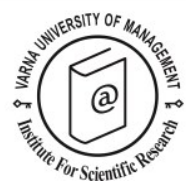

\title{
Understanding the relation between serious surfing, surfing profile, surf travel behaviour and destination attributes
}

\section{preferences}

\begin{abstract}
Ana Cristina Portugal ${ }^{1}$, Francisco Campos $^{2}$, Fernando Martins ${ }^{3}$ and Ricardo Melo ${ }^{4}$
\end{abstract}
Received: 15/06/2015 Accepted: 21/11/2016

\begin{abstract}
1 Polytechnic Institute of Coimbra, Coimbra Education School, Coimbra, Portugal; email: anacristinaportugal@gmail.com

2 Polytechnic Institute of Coimbra, Coimbra Education School, ASSERT, Coimbra, Portugal; email: francicampos@gmail.com

3 Polytechnic Institute of Coimbra, Coimbra Education School, ASSERT, Coimbra, Portugal; email: fmlmartins@esec.pt

${ }^{4}$ Polytechnic Institute of Coimbra, Coimbra Education School, ASSERT, IRNIST, Rua Dom João III, Solum, 3030-329 Coimbra, Portugal; Phone: 00351239793 120; E-mail: ricardo.es.melo@gmail.com

* Corresponding author
\end{abstract}

\begin{abstract}
Surfing is a sporting activity that has become a major business, integrated in the leisure and tourism industries. Due to the impact of surf tourism and to the surfers' characteristics featured by the time and effort they invest in surfing and their propensity to travel in search for the perfect wave, it is important to understand if the six serious leisure qualities (perseverance, career, effort, benefits, ethos and identity) are related with socio-demographic characteristics, surfing profile, surf travel behaviour and surfing destination attributes preferences. Aiming to achieve these goals, an online survey (in the form of a questionnaire) was applied to a casual sample of 200 surfers in Portugal. The results of this study demonstrate that surfers exhibit the six serious leisure qualities and have a strong disposition to travel for surfing. Moreover, the results highlight that surfers value mainly the surfing natural conditions when choosing a surfing travel destination. Statistical tests also allowed concluding that socio-demographic variables are not good predictors of serious surfing, although serious surfing is correlated with surfing profile, surf travel behaviour and surfing destination attributes preferences. This data enables to provide important information that can be used to strengthen management strategies by surf tourism industry providers.
\end{abstract}

(C) 2017 Varna University of Management. All rights reserved

Keywords: destination attributes preferences, serious leisure, sport tourism, surf tourism, travel behaviour

Citation: Portugal, A., F. Campos, F. Martins and R. Melo (2017) Understanding the relation between serious surfing, surfing profile, surf travel behaviour and destination attributes preferences. European Journal of Tourism Research 16, pp. 57-73 
Understanding the relation between serious surfing, surfing profile, surf travel behaviour and destination attributes preferences.

\section{Introduction}

\section{Surf tourism}

Surfing is a wave activity with its roots in Hawaiian culture and tradition (Buckley, 2002a). Since the early 1900's, surfing has grown as sport of Western civilization (Dolnicar \& Fluker, 2003b). Since the 1960's, the popularity of surfing has progressively increased (Barbieri \& Sotomayor, 2013; Ponting, 2008) due to the cultural changes of that period (Wheaton, 2010). Surf tourism started with independent adventure travellers searching for new surfing spots, driven by the quality of the surfing experience in other regions or climates (Barbieri \& Sotomayor, 2013). This kind of travel peaked in the 1960s because of the image of surfing culture delivered by mass media, as well as more affordable travel and the development of lighter materials (Barbieri \& Sotomayor, 2013; Lazarow, Miller, \& Blackwell, 2008). Surf tourism gained economic, social and environmental significance and has become a significant component of the adventure (sport) tourism sector (Buckley, 2002a; 2002b). Surf tourism is generally defined as travelling at least $40 \mathrm{~km}$ away from home, to domestic or international destinations, staying for at least one night and no more than 12 months, with surfing the primary purpose for travel. This includes active participants in surfing activities, as well as the spectators of events and those who follow them on their surfing trips (Buckley, 2002a; Dolnicar \& Fluker 2003a, 2003b, 2004; Fluker, 2003; Ponting, 2008).

Nowadays, surf travellers rely on surfing tour operators to help them manage their surfing trips, which has led to a "global industry involving thousands of tour operators, village home stays, resorts, charter boats, wholesalers, retail travel agents, and vertically integrated service combinations around the world" (Barbieri \& Sotomayor, 2013, p. 112). Recent research calculated that 112 countries have available surfing tours or surfing-related information for tourists (Ponting, 2008), fostering a multimillion-dollar industry that stimulates local economies (Barbieri \& Sotomayor, 2013).

The growth of surfing and surf tourism sector has gained academic attention (Martin \&
Assenov, 2012). Surfing research started in the 1970's (e.g., Kelly, 1973), and continued into the 1980's (e.g., Johnson \& Orbach, 1986; Markrich, 1988) and 1990's (e.g., Breedveld, 1995; Poizat-Newcomb, 1999a, 1999b). However, the growing body of literature specifically on surf tourism emerged in the $21^{\text {st }}$ century (Martin \& Assenov, 2012), especially in the last ten years. During that period, a variety of topics have been covered, such as analyses of surfers' demographic and economic statistics, travel patterns, behaviour and preferences (e.g. Buckley, 2002a, 2012; Dolnicar \& Fluker, 2003b), the surfing imaginary (e.g. Ponting, 2008, 2009; Ponting \& McDonald, 2013), analyses of conservation and the sustainability of surf tourism (e.g. Buckley, 2002a, 2002b; Martin \& Assenov, 2014a, 2014b; O'Brien \& Ponting, 2013; Ponting \& O'Brien, 2014) and the impact of surfing events (e.g. Getz \& Fairley, 2003; O’Brien, 2007).

The surfing industry in Portugal is also growing but there are no publications that identify its global economic significance. There is some evidence to indicate the growth of this sector, particularly the growth in the number of surfers (Melo, 2013), the growth in the development of more specialized services such as surf schools and surf camps, and the increase in the market for surfing-related consumer brands (Moutinho, Dionísio, \& Leal, 2007). Portugal is one of the best countries in Europe in which to develop surfing activities: it has a continental coast of almost $1000 \mathrm{~km}$, hosting large numbers of beaches with excellent surfing quality. These natural conditions, along with internationally renowned spots such as Ericeira (recognized during 2011 as the first World Surf Reserve in Europe, and the second one in the entire world) and Peniche (the Portuguese Capital of the Wave), and the organization of national and international top level events such as the World Surf Leagues, has allowed Portugal to create a positive destination image related to surfing (Melo, 2013).

\section{Surfing and serious leisure}

Serious leisure is a perspective that was introduced by Stebbins (1982) to analyse the seriousness with which some individuals take some leisure activities, including those who 
participate in sport and tourism activities (e.g. surfing). Serious leisure was defined by Stebbins (1992) as "the systematic pursuit of an amateur, a hobbyist, or a volunteer activity that participants find so substantial and interesting that, in the typical case, they launch themselves on a career centred on acquiring and expressing its special skills, knowledge, and experience" (p.3). Serious leisure is also defined in contrast with casual leisure by six interrelated qualities: perseverance, career development, personal effort, durable benefits, unique ethos, and strong identity (Stebbins, 2007).

Recent research has associated serious leisure, among others, with:

a) recreational and leisure activities, including, art photography (Spurgin, 2008), birdwatching (Cole \& Scott 1999; Tsaur \& Liang, 2008), fishing (Yoder, 1997), and volunteering (Stebbins, 1996b);

b) sport activities, including, climbing (Dilley \& Scraton, 2010), climbing, kayaking and snowboarding (Stebbins, 2005), cycling (O'Connor \& Brown, 2010), golfing (Siegenthaler \& O'Dell, 2003), swimming (Hastings, Kurth, Schloder, \& Cyr, 1995), whitewater kayaking (Bartram, 2001), and among sport fans (Gibson, Willming, \& Holdnak, 2002; Jones, 2000);

c) tourism, including, cultural tourism (Stebbins, 1996a), indigenous tourism (TsungChiung, Chyong-Ru, \& Wan-Chen, 2012) and;

d) sport tourism, including, MTB event travel (Getz \& McConnell, 2011), kayaking adventure tour (Kane \& Zink, 2004), marathon tourism (Smith, Costello \& Warren, 2010), and surf tourism (Barbieri \& Sotomayor, 2013; Campos, Portugal, \& Melo, 2017; Cheng \& Tsaur, 2012).

Most of the studies on serious leisure have employed qualitative methodologies, using the six characteristics to explore the nature of an activity (e.g. Getz \& McConnell, 2011; Gibson et al., 2002; Kane \& Zink, 2004; Smith, Costello, \& Warren, 2010). However, more recent studies have used quantitative methodologies to examine the relationship between serious leisure with other variables (e.g., Barbieri \& Sotomayor, 2013; Campos, Portugal \& Melo, 2017; Cheng \& Tsaur, 2012;
Gould, Moore, McGuire \& Stebbins, 2008; Tsaur \& Liang, 2008).

In the last approach, Gould, et al. (2008) developed the Serious Leisure Inventory and Measure (SLIM) as an instrument to access serious leisure, composed of 54 operational items organized into 18 sub-dimensions representing the six defining qualities of serious leisure. Other studies were also developed from the SLIM, on chess (Gould, Moore, Karlin, Gaede, Walker, \& Dotterweich 2011), birdwatching (Lee \& Scott, 2013). From this, Barbieri and Sotomayor (2013) investigated the relationship between serious leisure, surf travel behaviour and destination preferences, confirming that surfers show high levels in the six qualities of serious leisure, and have a strong disposition for surf tourism. However, serious leisure qualities were not shown to be good predictors of surf travel behaviour (Barbieri \& Sotomayor, 2013).

In addition, Tsaur and Liang (2008) developed an instrument to measure the serious leisure construct, dividing it into six dimensions and 21 items, to study birdwatchers and investigate the relationship between serious leisure traits and recreation specialization. Other studies were also developed from this (Campos, Portugal, \& Melo, 2017; Cheng \& Tsaur, 2012). Cheng and Tsaur (2012) studied the relationship between surfers' serious leisure characteristics and recreational involvement. They demonstrated that ethos, identity with surfing, significant personal efforts and career pursuits are all strong indicators of surfers' serious leisure characteristics, and that attraction and selfexpression (dimensions of recreational involvement) have the most impact, demonstrating that surfers with higher serious leisure characteristics have a higher recreational involvement.

More recently, Campos, Portugal and Melo (2017) presented a study that focuses on the segmentation of surfers in Portugal, according to the seriousness of their surfing involvement. The results from this study allow affirming that surfing can be considered a serious leisure activity, and demonstrating that surfers exhibit the six serious leisure qualities, especially related to expected benefits, career and 
identity, and have a strong disposition for surf tourism.

In summary, previous studies showed that surfers share the six serious leisure qualities:

a) perseverance - the need for surfers to persevere in attaining the skills and knowledge required to master the waves (Butts, 2001; Ponting, 2008) but to also negotiate the many constraints they face, such as physical risks, cancelling social appointments when the waves are good, and waiting for the good waves (Butts, 2001);

b) career - surfing creates the possibility of finding a career by progressing into more difficult waves (Butts, 2001), and by travelling greater distances or to special destinations to practice (Dolnicar \& Flucker, 2003b);

c) effort - serious surfers are characterized by the long-term personal effort they make to master their skills (Dolnicar \& Fluker, 2003b) and to understand and appropriate the subculture's attitudes, knowledge and values, through a process of instruction and socialization by their peers, and by digesting information from books, videos and specialist magazines (Butts, 2001);

d) benefits - evidence of durable benefits was found in the literature, especially in the form of gaining courage, self-invigoration, selfconfidence and fitness (Buckley, 2012);

e) ethos - in acquiring the necessary skills and adopting appropriate behaviour surfers can, over time, become accepted member of the surfing subculture and attain their peers recognition, thus sharing the unique ethos that is present in this subculture (Butts, 2001);

f) identity - surfers exhibit a tribal behaviour characterized by a strong identification which is externalized by taking their boards whenever they go to the beach (Moutinho et al., 2007), as well as through their manners of dress and language (Butts, 2001).

\section{Purpose and objectives of the study}

The study of serious leisure in sport and tourism, particularly surfing, is important because it allows an understanding of the participants' behaviour. In spite of the size and economic impact of surfing and the importance of determining the surfers' characteristics, few studies have examined this form of sport tourism and even fewer investigated the 60 application of serious leisure among surfers. This study was developed during the year of 2014 aiming to fill this gap in the literature. Based on the serious leisure perspective, this article addresses four main objectives: a) to verify if socio-demographic characteristics are good predictors of serious surfing; b) to understand the relation between serious surfing and surfing profile; c) to identify the role of serious surfing on surfing travel behaviour; and d) to examine if the six serious surfing qualities are related with surfing destination attributes preferences.

\section{Methodology}

This study used an online survey (in the form of a questionnaire) to collect data. The questionnaire was composed of 5 groups of questions, including: a) socio-demographic characteristics (nationality, sex, age, marital status, education level, working situation, and income); b) surfing behaviours (currently surfing or not; number of years surfing, number of days surfing per week, season of the year surfing); c) surfing travel behaviour (past surfing trips, surfing destinations, length of surfing trips, travelling companionship, surfing destination choice, spending per day, willingness to take a surfing trip in the future, and future surfing destinations); d) surfing destination attributes [25 items adapted from Dolnicar and Fluker (2003b), Barbieri and Sotomayor (2013) and Reis and Jorge (2012), measured in a 7-point rating scale, ranging from 1 (not at all important) to 7 (totally important)]; and e) serious leisure related with surfing [21 items adapted from Cheng and Tsaur (2012), measured in a 7-point rating scale, ranging from 1 (completely disagree) to 7 (completely agree)]. The questionnaire was created in two languages (Portuguese and English), with identical questions and application methods [using translation and back translation (Hill \& Hill, 2002)], and was validated by pre-test application and expert examination (face validity). The questionnaire was built in Google Forms platform and a casual sample technique was used (Marôco, 2011).

The target population included those who have practiced surfing activities in Portugal, and who were aged 18 years or older. The questionnaire 
was distributed in Portugal and abroad through websites and social media, and more precisely through surfers' schools and surfing groups' Facebook page. The questionnaire was applied from June until October 2014, and 200 answers were obtained.

Data was analysed in the IBM SPSS (version 21). Descriptive analyses were first conducted to present the socio-demographic characteristics of responding surfers, to describe surfing profile and surfing travel behaviour, and to analyze destination attributes preferences and the seriousness of surfing.

Factorial analysis, by Principal Component Analysis (PCA), was used for data reduction purposes (Marôco, 2011). Surfing destination attributes (25 items), and serious leisure related to surfing (21 items) were reduced to a smaller number of dimensions or PC (respectively, five and six dimensions). The following criteria were used to decide the number of components to extract (Marôco,
2011): i) Kaiser-Meyer-Olkin (KMO) value obtained greater than 0.6 and the significance value (using Bartlett test) below 0.1, in order to reject the null hypothesis and prove the suitability of the analytical method for the treatment of data; ii) eigenvalue greater than 1.0 or the scree Plot indicating the suitable number of PC that can be extracted before the amount of explained variance becomes too small; iii) communalities, representing the percentage of common variance between items and extracted factors; iv) factor loadings, higher than $40 \%$; and v) variance explained percentage, at least $60 \%$ of the total variance was considered satisfactory. In addition, the reliability coefficient to assess internal consistency (Cronbach's alpha coefficient) was analysed for all dimensions and globally structured (Marôco, 2011). One item from both scales was withdrawn from the final factorial solution, to accomplish the presented criterion: destination with good cultural heritage (surfing destination attributes scale), and I persevere in

Table 1. Socio-demographic characteristics of responding surfers

\begin{tabular}{|c|c|c|}
\hline Socio-demographic indicators & $\mathbf{N}$ & $\%$ \\
\hline \multicolumn{3}{|l|}{ Nationality } \\
\hline Portuguese & 177 & 88.5 \\
\hline Others & 23 & 11.5 \\
\hline \multicolumn{3}{|l|}{ Sex } \\
\hline Male & 165 & 82.5 \\
\hline Female & 35 & 17.5 \\
\hline \multicolumn{3}{|l|}{ Age group } \\
\hline $18-30$ & 72 & 36.0 \\
\hline $31-43$ & 99 & 49.5 \\
\hline$\geq 44$ & 29 & 14.5 \\
\hline Mean (in years) & 34 & \\
\hline Standard deviation & \pm 9 & \\
\hline \multicolumn{3}{|l|}{ Marital Status } \\
\hline Single & 119 & 59.5 \\
\hline Married & 68 & 34.0 \\
\hline Others & 13 & 6.5 \\
\hline \multicolumn{3}{|l|}{ Education Level } \\
\hline $9^{\text {th }}$ Grade or less & 7 & 3.5 \\
\hline Secondary School (12 ${ }^{\text {th }}$ grade $)$ & 42 & 21.0 \\
\hline Higher Education studies (Graduated) & 100 & 50.0 \\
\hline Post-graduate studies (Master or PhD) & 51 & 25.5 \\
\hline \multicolumn{3}{|l|}{ Working situation } \\
\hline Working to others & 108 & 54.0 \\
\hline Owners of companies or self employees & 44 & 22.0 \\
\hline Student & 40 & 20.0 \\
\hline Others & 8 & 4.0 \\
\hline \multicolumn{3}{|l|}{ Income } \\
\hline Without income & 28 & 14.0 \\
\hline$\leq € 500$ & 14 & 7.0 \\
\hline $501-€ 1000$ & 57 & 28.5 \\
\hline$€ 1001-€ 1500$ & 30 & 15.0 \\
\hline$>€ 1500$ & 19 & 35.5 \\
\hline
\end{tabular}


surfing to conquer difficulties (serious surfing scale).

Standard multiple linear regression were used to verify if socio-demographic characteristics (independent variables) are good predictors of serious surfing (dependent variables); to understand the relation between serious surfing (independent variables) and surfing profile (dependent variables); to identify the role of serious surfing (independent variables) on surfing travel behaviour (dependent variables) and; to examine if the six serious surfing qualities (independent variables) are related with surfing destination attributes preferences (dependent variables). The model assumptions were analysed and are generally satisfied, namely, the normal distribution, homogeneity and errors independency. No multicolinearity was found among the independent variables because variance inflation factor (VIF) were below conservative maximum scores $(<5.0)$ (Marôco, 2011).
Binary logistic regression, using enter method, was also performed to predict the relation between serious surfing (independent variables) and surfing travel behaviour average length of surfing trips, travelling companionship, surf destinations choice and future destinations (dependent variables). The model assumptions were analyzed and are generally satisfied (Marôco, 2011).

\section{Results}

Socio-demographic characteristics of respondents

The descriptive analysis of nationality, sex, age, marital status, level of education, working situation and income variables allowed the characterization of the socio-demographic profile of the surfers in our sample (Table1). The results show that $88.5 \%$ of respondents were Portuguese and the large majority $(82.5 \%)$ were male. The average age was 34 years old $(S D= \pm 9)$, with $36 \%$ in the aged $18-30$ group, $49.5 \%$ in the $31-43$ years group, and

Table 2. Surfing profile of responding surfers

\begin{tabular}{|c|c|c|}
\hline Surfing profile & $\mathbf{N}$ & $\%$ \\
\hline \multicolumn{3}{|l|}{ Current behaviour $(n=200)$} \\
\hline Currently surfing & 169 & 84.5 \\
\hline Do not surf currently but I did in the past & 31 & 15.5 \\
\hline \multicolumn{3}{|l|}{ Number of years surfing $(n=169)^{*}$} \\
\hline Less than 1 year & 10 & 5.9 \\
\hline $1-2$ years & 9 & 5.3 \\
\hline $3-5$ years & 57 & 33.7 \\
\hline $6-10$ years & 51 & 30.2 \\
\hline $11-20$ years & 30 & 17.8 \\
\hline More than 20 years & 12 & 7.1 \\
\hline \multicolumn{3}{|l|}{ Preferred surfing season $(n=169)^{*}$} \\
\hline Spring & 3 & 1.8 \\
\hline Summer & 10 & 5.9 \\
\hline Autumn & 4 & 2.4 \\
\hline Winter & 4 & 2.4 \\
\hline During all year & 148 & 87.6 \\
\hline \multicolumn{3}{|l|}{ Number of surfing days per week $(n=169)^{*}$} \\
\hline Less than a 1 day per week & 25 & 14.8 \\
\hline 1 day per week & 22 & 13 \\
\hline 2 days per week & 50 & 29.6 \\
\hline 3 days per week & 33 & 19.5 \\
\hline 4 days per week & 23 & 13.6 \\
\hline 5 days per week & 7 & 4.1 \\
\hline 6 days per week & 4 & 2.4 \\
\hline 7 days per week & 5 & 3.0 \\
\hline \multicolumn{3}{|c|}{ Financial willingness to evolve in surfing $(n=169)^{*}$} \\
\hline None since I don't earn income yet & 12 & 7.1 \\
\hline None since I can afford basic needs only & 41 & 24.3 \\
\hline Some since I live with some financial comfort & 87 & 51.5 \\
\hline Total since I have financial availability & 29 & 17.2 \\
\hline
\end{tabular}

\footnotetext{
* This only includes those who currently surfing.
} 
$14.5 \%$ aged 43 or older. The respondents were mostly single $(59.5 \%)$ and a third of them were married $(34.0 \%)$. The majority $(75.5 \%)$ had higher levels of education, including postgraduate studies $(25.5 \%)$, mainly working for others $(54.0 \%)$ as well as being selfemployed or owning companies $(22.0 \%)$. The majority $(50.5 \%)$ of responding surfers also indicated that they have income above the Portuguese average (>€1000 per month).

\section{Surfing profile of respondents}

In terms of the surfing profile of respondents (Table 2), the large majority $(84.5 \%)$ stated that, at the time of the study, they were surfers, and only $15.5 \%$ were not practicing at that time, but had done in the past. The participants are mainly $(55.1 \%)$ experienced surfers, and the majority $(49.1 \%)$ stated they surf $2-3$ times per week, $23.1 \%$ stated that they surf 4 or more days per week. The large majority $(87.6 \%)$ also

Table 3. Surf travel behaviour among responding surfers.

\begin{tabular}{|c|c|c|}
\hline Indicators of surf travel behaviour & $\mathbf{N}$ & $\%$ \\
\hline \multicolumn{3}{|l|}{ Past surfing trips $(n=200)$} \\
\hline Have taken at least one surfing trip (at least 2 days) & 160 & 80.0 \\
\hline Have never taken a surfing trip & 40 & 20.0 \\
\hline \multicolumn{3}{|l|}{ Surfing destinations in the last 3 years $(n=160)^{*}$} \\
\hline Mainly domestic destinations & 106 & 66.3 \\
\hline Mainly international destinations & 54 & 33.7 \\
\hline \multicolumn{3}{|l|}{ Average length of surfing trips $(n=160)^{*}$} \\
\hline Less than 1 week & 47 & 29.4 \\
\hline $1-2$ weeks & 88 & 55.0 \\
\hline 3-4 weeks & 19 & 11,8 \\
\hline 1- 2 months & 6 & 3.8 \\
\hline$>2$ months & 0 & 0.0 \\
\hline \multicolumn{3}{|l|}{ Travelling companionship $(n=160)^{*}$} \\
\hline Alone & 16 & 10.0 \\
\hline With family (including children) & 27 & 16.9 \\
\hline Partner & 25 & 15.6 \\
\hline Friends & 83 & 51.9 \\
\hline Organized group & 9 & 5.6 \\
\hline \multicolumn{3}{|l|}{ Surfing destination choice $(n=160)^{*}$} \\
\hline By the internet & 37 & 23.1 \\
\hline Friends suggestions & 66 & 41.2 \\
\hline Magazines/Journals/Other media & 24 & 15.0 \\
\hline Events/Championships happening at the destination & 10 & 6.3 \\
\hline Previous visit & 11 & 6.9 \\
\hline Tourist guide book & 1 & 0.6 \\
\hline Travel agency & 1 & 0.6 \\
\hline Others & 10 & 6.3 \\
\hline \multicolumn{3}{|l|}{ Spending per day $(n=160)^{*}$} \\
\hline$<20 €$ & 20 & $12,5 \%$ \\
\hline $20 €-40 €$ & 44 & $27,4 \%$ \\
\hline $41 €-80 €$ & 55 & $34,3 \%$ \\
\hline $81 €-100 €$ & 16 & $10,0 \%$ \\
\hline $101 €-120 €$ & 10 & $6,3 \%$ \\
\hline $121 €-140 €$ & 6 & $3,8 \%$ \\
\hline $141 €-180 €$ & 3 & $1,9 \%$ \\
\hline $181 €-200 €$ & 2 & $1,3 \%$ \\
\hline$>200 €$ & 4 & $2,5 \%$ \\
\hline \multicolumn{3}{|l|}{ Willingness to take a surf trip in the future $(n=200)$} \\
\hline Totally unwilling & 2 & 1.0 \\
\hline Not very unwilling & 1 & 0.5 \\
\hline Unwilling & 1 & 0.5 \\
\hline Nor unwilling nor willing & 18 & 9.0 \\
\hline Willing & 21 & 10.5 \\
\hline Very willing & 22 & 11.0 \\
\hline Totally willing & 135 & 67.5 \\
\hline \multicolumn{3}{|l|}{ Future surf destinations $(n=200)$} \\
\hline Mainly domestic destinations & 61 & 30.5 \\
\hline Mainly international destinations & 139 & 69.5 \\
\hline
\end{tabular}

* This only includes those who have taken a surfing trip. 
reported that they surf at all times of the year, and more than two thirds $(68.7 \%)$ have financial willingness to evolve in surfing.

\section{Surfing travel behaviour of respondents}

Regarding surfing travel behaviour (Table 3), the large majority $(80.0 \%)$ of respondents had taken a surf trip of at least 2 days. In the last 3 years, $66.3 \%$ had visited domestic destinations, while only $33.7 \%$ travelled primarily to international destinations. In terms of the average length of travel, the majority $(55.0 \%)$ had taken surf trips for $1-2$ weeks, $29.4 \%$ for less than 1 week, $11.8 \%$ for 3-4 weeks, and only 6 respondents (3.8\%) embarked on lengthy trips for 1-2 months. Surfers travelled mostly with friends (41.5\%), 16.9\% travelled with family (including children), $15.6 \%$ with the partner, and $10.0 \%$ alone. For the choice of surfing destination, $41.2 \%$ chose according to friends' suggestions, $23.1 \%$ chose through internet sites, $15.0 \%$ through the press, $6.9 \%$ according to prior visits, and $6.3 \%$ based on events/championships held previously in that destination. In terms of the amount of money spent per day, $40 \%$ spent less than $€ 40,50.6 \%$ between $€ 40-120$, and $9.4 \%$ more than $€ 120$. Regarding the intention to travel in the future, $67.5 \%$ demonstrated a total willingness to travel, and $69.5 \%$ decided on international destinations, showing that surfers present a high propensity for surf tourism.

Table 4. PCA results for the 5 components of surfing destination attributes

\begin{tabular}{|c|c|c|c|c|c|c|c|c|}
\hline $\begin{array}{l}\text { Principal } \\
\text { Components }\end{array}$ & Items & $\begin{array}{l}\text { Mean } \\
\text { Score }^{a}\end{array}$ & SD & $\begin{array}{l}\text { Factor } \\
\text { Loadings }\end{array}$ & $\begin{array}{l}\text { Mean } \\
\text { Score }^{a}\end{array}$ & SD & $\begin{array}{l}\text { Total } \\
\text { Variance }\end{array}$ & $\begin{array}{l}\text { Cronba } \\
\text { ch's a }\end{array}$ \\
\hline \multirow{8}{*}{$\begin{array}{l}\text { Surfing } \\
\text { infrastructures } \\
\text { and cultural } \\
\text { ambience }\end{array}$} & $\begin{array}{l}\text { Destination with local surf schools/ surf } \\
\text { camps }\end{array}$ & 3.0 & 1.9 & 0.759 & \multirow[t]{8}{*}{3.7} & \multirow[t]{8}{*}{1.2} & \multirow[t]{8}{*}{$18.9 \%$} & \multirow[t]{8}{*}{0.87} \\
\hline & $\begin{array}{l}\text { Destination with local rental/sale of } \\
\text { surfing equipment (surfing suits, boards, } \\
\text { etc.) }\end{array}$ & 3.6 & 1.8 & 0.738 & & & & \\
\hline & Popular surf destination & 3.4 & 1.6 & 0.721 & & & & \\
\hline & Good destination to meet other surfers & 4.5 & 1.7 & 0.697 & & & & \\
\hline & $\begin{array}{l}\text { Destination with features for sports } \\
\text { physical practice }\end{array}$ & 4.3 & 1.8 & 0.693 & & & & \\
\hline & $\begin{array}{l}\text { Destination with supporting beach } \\
\text { infrastructures (showers, lockers, bar, } \\
\text { terrace) }\end{array}$ & 3.6 & 1.8 & 0.665 & & & & \\
\hline & $\begin{array}{l}\text { Destination with diversity of services } \\
\text { (commerce, attractions, etc.) }\end{array}$ & 3.9 & 1.5 & 0.621 & & & & \\
\hline & Destination with attractive night life & 3.3 & 1.5 & 0.567 & & & & \\
\hline \multirow{7}{*}{$\begin{array}{l}\text { Hospitality } \\
\text { and touristic } \\
\text { facilities }\end{array}$} & $\begin{array}{l}\text { Destination with good quality of } \\
\text { accommodation }\end{array}$ & 4.7 & 1.5 & 0.772 & \multirow[t]{7}{*}{5.0} & \multirow[t]{7}{*}{1.0} & \multirow[t]{7}{*}{$16.4 \%$} & \multirow[t]{7}{*}{0.84} \\
\hline & Safe destination & 5.7 & 1.3 & 0.700 & & & & \\
\hline & $\begin{array}{l}\text { Destination with family and friends } \\
\text { facilities (infrastructures and equipment) }\end{array}$ & 4.7 & 1.6 & 0.683 & & & & \\
\hline & $\begin{array}{l}\text { Destination with good natural } \\
\text { environment quality }\end{array}$ & 5.9 & 1.2 & 0.682 & & & & \\
\hline & Destination with good hospitality & 5.4 & 1.4 & 0.666 & & & & \\
\hline & Destination with good gastronomy & 4.7 & 1.5 & 0.597 & & & & \\
\hline & Destination with easy access & 4.2 & 1.5 & 0.544 & & & & \\
\hline \multirow{3}{*}{$\begin{array}{l}\text { Surfing } \\
\text { natural } \\
\text { conditions }\end{array}$} & Destination with variety of places to surf & 6.2 & 1.1 & 0.829 & \multirow[t]{3}{*}{6.0} & \multirow[t]{3}{*}{0.9} & \multirow[t]{3}{*}{$8.8 \%$} & \multirow[t]{3}{*}{0.66} \\
\hline & $\begin{array}{l}\text { Destination with good waves quality } \\
\text { (wave consistency, good swell, wave } \\
\text { type variety) }\end{array}$ & 6.5 & 0.8 & 0.772 & & & & \\
\hline & Destination with secret locations to surf & 5.3 & 1.6 & 0.600 & & & & \\
\hline \multirow{3}{*}{$\begin{array}{l}\text { No crowd } \\
\text { destination }\end{array}$} & Destination close to the local community & 5.1 & 1.4 & 0.711 & \multirow[t]{3}{*}{5.3} & \multirow[t]{3}{*}{1.0} & \multirow[t]{3}{*}{$7.7 \%$} & \multirow[t]{3}{*}{0.51} \\
\hline & $\begin{array}{l}\text { Destination with low costs (low cost of } \\
\text { living) }\end{array}$ & 5.4 & 1.4 & 0.570 & & & & \\
\hline & Destination never crowded & 5.4 & 1.3 & 0.539 & & & & \\
\hline \multirow{3}{*}{$\begin{array}{l}\text { Natural } \\
\text { amenities }\end{array}$} & Destination with good water temperature & 5.0 & 1.4 & 0.840 & \multirow[t]{3}{*}{5.2} & \multirow[t]{3}{*}{1.0} & \multirow[t]{3}{*}{$7.6 \%$} & \multirow[t]{3}{*}{0.65} \\
\hline & Destination with good climate & 5.7 & 1.1 & 0.735 & & & & \\
\hline & $\begin{array}{l}\text { Destination with easy access to surf } \\
\text { spots }\end{array}$ & 4.9 & 1.4 & 0.449 & & & & \\
\hline
\end{tabular}




\section{Surfing destination attributes}

The analysis of the factorial structure of the 24 items of the surfing destination attributes scale (Table 4) was performed by exploratory factor analysis, with extraction of factors by the PCA method, using varimax rotation. The criteria defined to accept the factorial structure was, respectively: KMO (0.84), Bartlett test ( $p$ value $=0.000$ ), eigenvalue greater than 1.0 or the scree plot elbow rule confirmed, factor loadings higher than $40.0 \%$, and $69.4 \%$ of total variance explained by the 5 components. The internal consistency, evaluated by Cronbach's alpha coefficient, is considered good for the global factorial structure (0.88) and at least acceptable for the 5 dimensions (Marôco, 2011).
The most valued attributes, when choosing a surf travel destination, are those related to the surfing natural conditions dimension $(M=6.0 \pm 0.9)$, especially good waves quality $(M=6.5 \pm 0.8)$ and diversity of places to surf $(M=6.2 \pm 1.1)$. A destination with natural environment quality $(M=5.9 \pm 1.2)$, good climate $(M=5.7 \pm 1.1)$, and safety $(M=5.7 \pm 1.3)$, is cited as possessing other valued surfing destination attributes. On the other hand, surfing infrastructures and cultural ambience $(M=3.7 \pm 1.2)$ is the overall surfing destination attribute dimension that is less valued, especially in terms of local surf schools/surf camps $(M=3.0 \pm 1.9)$, and attractive night life $(M=3.3 \pm 1.5)$.

Table 5. PCA results for the 6 components of serious surfing

\begin{tabular}{|c|c|c|c|c|c|c|c|c|}
\hline $\begin{array}{l}\text { Principal } \\
\text { Components }\end{array}$ & Items & $\begin{array}{l}\text { Mean } \\
\text { Score }^{a}\end{array}$ & SD & $\begin{array}{l}\text { Factor } \\
\text { Loadings }\end{array}$ & $\begin{array}{l}\text { Mean } \\
\text { Score }\end{array}$ & SD & $\begin{array}{l}\text { Total } \\
\text { Variance }\end{array}$ & $\begin{array}{l}\text { Cronba } \\
\text { ch's } \alpha\end{array}$ \\
\hline \multirow[t]{4}{*}{ Career } & To me, surfing is an important part of life & 6.0 & 1.4 & 0.847 & 5.7 & 1.3 & $19.0 \%$ & 0.85 \\
\hline & Without surfing, my life would be boring & 5.0 & 1.9 & 0.711 & & & & \\
\hline & $\begin{array}{l}\text { I'm willing to engage in surfing activities } \\
\text { for the long-term }\end{array}$ & 6.3 & 1.2 & 0.773 & & & & \\
\hline & $\begin{array}{l}\text { I dedicate significant time and effort to } \\
\text { surfing }\end{array}$ & 5.2 & 1.6 & 0.787 & & & & \\
\hline \multirow[t]{4}{*}{ Ethos } & $\begin{array}{l}\text { I meet many friends by attending surfing } \\
\text { activities }\end{array}$ & 5.5 & 1.6 & 0.684 & 5.2 & 1.4 & $15.7 \%$ & 0.88 \\
\hline & $\begin{array}{l}\text { I share a sense of trust and value with my } \\
\text { colleagues in surfing }\end{array}$ & 5.5 & 1.4 & 0.749 & & & & \\
\hline & $\begin{array}{l}\text { In private, I will attend activities and } \\
\text { gatherings with my surfing friends }\end{array}$ & 5.2 & 1.6 & 0.805 & & & & \\
\hline & $\begin{array}{l}\text { In private, I can discuss everything with } \\
\text { my surfing friends }\end{array}$ & 4.5 & 1.7 & 0.839 & & & & \\
\hline \multirow[t]{3}{*}{ Perseverance } & $\begin{array}{l}\text { I would participate in surfing even though } \\
\text { I'm very busy }\end{array}$ & 5.6 & 1.5 & 0.853 & 5.3 & 1.5 & $12.0 \%$ & 0.72 \\
\hline & $\begin{array}{l}\text { I would participate in surfing even though } \\
\text { I'm very tired }\end{array}$ & 5.0 & 1.8 & 0.914 & & & & \\
\hline & $\begin{array}{l}\text { I would participate in surfing even though } \\
\text { I'm feeling down }\end{array}$ & 5.6 & 1.8 & 0.701 & & & & \\
\hline \multirow[t]{3}{*}{ Effort } & $\begin{array}{l}\text { I'm willing to spend time and money in } \\
\text { training for surf techniques }\end{array}$ & 4.6 & 1.7 & 0.803 & 4.3 & 1.4 & $9.8 \%$ & 0.72 \\
\hline & $\begin{array}{l}\text { I'm willing to purchase surfing books and } \\
\text { video tapes to enhance my surfing } \\
\text { techniques }\end{array}$ & 3.6 & 1.8 & 0.884 & & & & \\
\hline & $\begin{array}{l}\text { I have the opportunity to achieve self- } \\
\text { actualization by attending surfing } \\
\text { activities }\end{array}$ & 4.8 & 1.7 & 0.442 & & & & \\
\hline \multirow[t]{3}{*}{ Identity } & $\begin{array}{l}\text { I believe no other leisure activities can } \\
\text { replace surfing }\end{array}$ & 5.2 & 1.9 & 0.484 & 5.5 & 1.4 & $8.9 \%$ & 0.77 \\
\hline & I enjoy watching TV shows on surfing & 5.6 & 1.5 & 0.751 & & & & \\
\hline & $\begin{array}{l}\text { I like to discuss interesting things about } \\
\text { surfing with others }\end{array}$ & 5.5 & 1.4 & 0.606 & & & & \\
\hline \multirow[t]{3}{*}{ Benefits } & $\begin{array}{l}\text { I achieve pleasure and satisfaction by } \\
\text { attending surfing activities }\end{array}$ & 6.5 & 1.6 & 0.455 & 6.0 & 1.1 & $8.1 \%$ & 0.70 \\
\hline & $\begin{array}{l}\text { I achieve a sense of fulfilment by } \\
\text { attending surf activities }\end{array}$ & 5.6 & 1.6 & 0.646 & & & & \\
\hline & $\begin{array}{l}\text { I enhance my physique by attending } \\
\text { surfing activities }\end{array}$ & 5.6 & 1.5 & 0.576 & & & & \\
\hline
\end{tabular}




\section{Serious surfing}

The analysis of the factorial structure of the 20 items of the serious surfing scale (Table 5) was also performed by PCA, using varimax rotation. The criteria defined to accept the factorial structure was, respectively: KMO (0.86), Bartlett test ( $p$ value $=0.001)$, eigenvalue greater than 1.0 or scree plot elbow rule confirmed, factor loadings higher than $40.0 \%$, and $73.1 \%$ of the total variance explained by the 6 main components. The internal consistency, evaluated by Cronbach's alpha coefficient, is considered good for the global factorial structure (0.89) and at least acceptable for the 6 dimensions (Marôco, 2011).

Overall, the 20 items were classified with high scores $(M=5.3 \pm 0.6)$. The most valued serious surfing qualities were Benefits $(M=6.0 \pm 1.1)$ [I achieve a sense of fulfilment by attending surfing activities $(M=6.5 \pm 1.6)]$ and Career $(M=5.7 \pm 1.3)\left[I^{\prime} m\right.$ willing to engage in surfing activities for the long-term $(M=6.3 \pm 1.2)$; to me, surfing is an important part of life $(M=6.0 \pm 1.4)]$. These results show the importance and centrality of surfing to surfers' lives.

On the other hand, Effort $(M=4.3 \pm 1.4)$ is the serious surfing quality with the lowest scores, especially the item, I'm willing to purchase surfing books and video tapes to enhance my surfing techniques $(M=3.6 \pm 1.8)$. These results can be explained by the fact that most of the surveyed individuals were already experienced surfers with high skills, and they did not need to spend time and money on further developing their surfing in this way.

Socio-demographic characteristics as predictors of serious surfing

Results of statistical tests (Table 6) indicated that the socio-demographic characteristics are not good predictors of serious surfing qualities, especially in ethos $\left(F_{(6,193)}=1.176 ; p\right.$-value $=$ $0.321)$, perseverance $\left(F_{(6,193)}=0.574 ; p\right.$-value $=0.751)$, identity $\left(F_{(6,193)}=0.979 ; p\right.$-value $=$ $0.440)$ and benefits $\left(F_{(6,193)}=1.463 ; p\right.$-value $=$ $0.193)$.

The socio-demographic characteristics explains $12.5 \%$ of career dimension and the model is statistically significant $\left(F_{(6,193)}=4.578 ; p\right.$-value $=0.000)$. Male sex $(\beta=0.299, \mathrm{t}(193)=4.218$, $p$-value $=0.001$ ) was revealed to be a significant estimator of career dimension. Considering the positive $\beta$ value, men present higher values in this dimension than women.

Effort dimension can also be predicted by socio-demographic characteristics. The model explains $7.8 \%$ of effort, and is statistically significant $\left(F_{(6,193)}=2.737 ; p\right.$-value $\left.=0.014\right)$. Male sex $(\beta=-.249, \mathrm{t}(193)=-3.421, p$-value $=$ $0.001)$ was revealed to be a significant estimator of effort dimension. Considering the negative $\beta$ value, men present lower values in this dimension than women.

The relation between serious surfing and surfing profile

Multiple linear regressions were also used to

Table 6. Multiple linear regressions of socio-demographic characteristics on serious surfing qualities

\begin{tabular}{lcccccc}
\hline $\begin{array}{l}\text { Independent Variables: Socio- } \\
\text { demographics }\end{array}$ & \multicolumn{7}{l}{$\begin{array}{l}\text { Dependent Variables: Serious surfing qualities } \\
\text { (standardized } \beta \text { and significance) }\end{array}$} \\
\cline { 2 - 7 } & Career & Ethos & Perseverance & Effort & Identity & Benefits \\
\hline Age & -0.193 & 0.123 & -0.072 & -0.051 & -0.050 & 0.051 \\
Sex (male) & $0.299^{*}$ & -0.067 & 0.026 & $-0.249^{*}$ & -0.030 & -0.088 \\
Marital status: & & & & & & \\
Single & -0.168 & -0.055 & 0.016 & -0.038 & -0.087 & 0.221 \\
Married & -0.248 & -0.133 & 0.037 & -0.042 & -0.050 & 0.240 \\
Level of Education & -0.001 & 0.026 & -0.017 & 0.109 & -0.085 & -0.110 \\
Income & 0.116 & 0.099 & 0.145 & 0.015 & 0.050 & -0.086 \\
\hline$R^{2}$ & 0.125 & 0.035 & 0.018 & 0.078 & 0.030 & 0.043 \\
Adjusted $\mathrm{R}^{2}$ & 0.097 & 0.005 & 0.132 & 0.050 & -0.001 & 0.014 \\
$p$-value & 0.001 & 0.321 & 0.751 & 0.014 & 0.440 & 0.193 \\
\hline
\end{tabular}

*Significant with Bonferroni adjusted critical value $(p<0.02)$. 
Portugal, A., F. Campos, F. Martins and R. Melo (2017) / European Journal of Tourism Research 16, pp. 57-73

Table 7. Multiple linear regressions of serious surfing on surfing profile

\begin{tabular}{|c|c|c|}
\hline \multirow[t]{2}{*}{ Independent Variables } & \multicolumn{2}{|c|}{$\begin{array}{l}\text { Dependent Variables } \\
\text { (standardized } \beta \text { and significance) }\end{array}$} \\
\hline & Surfing experience ${ }^{a}$ & Surfing frequency $\mathrm{b}$ \\
\hline Career & $0.180^{*}$ & $0.349^{*}$ \\
\hline Ethos & 0.063 & -0.159 \\
\hline Perseverance & 0.047 & $0.224^{*}$ \\
\hline Effort & $-0.407^{*}$ & $-0.338^{*}$ \\
\hline Identity & $-0.174^{*}$ & -0.082 \\
\hline Benefits & 0.041 & 0.108 \\
\hline $\mathrm{R}^{2}$ & 0.183 & 0.264 \\
\hline Adjusted $R^{2}$ & 0.153 & 0.237 \\
\hline$p$-value & 0.001 & 0.001 \\
\hline
\end{tabular}

Table 8. Multiple linear regressions of serious surfing on surf travel behaviour

\begin{tabular}{llll}
\hline Independent Variables & \multicolumn{2}{l}{$\begin{array}{l}\text { Dependent Variables } \\
\text { (standardized } \beta \text { and significance) }\end{array}$} \\
\cline { 2 - 4 } & Length of surfing trips ${ }^{\mathrm{a}}$ & Average spent per day ${ }^{\mathrm{b}}$ & $\begin{array}{l}\text { Willingness to travel } \\
\text { in the future }{ }^{\mathrm{b}}\end{array}$ \\
\hline Career & 0.111 & -0.128 & $0.526^{*}$ \\
Ethos & -0.150 & 0.121 & $0.160^{*}$ \\
Perseverance & -0.111 & -0.080 & 0.017 \\
Effort & -0.157 & -0.061 & -0.078 \\
Identity & 0.011 & 0.036 & -0.034 \\
Benefits & 0.095 & -0.088 & -0.076 \\
\hline $\mathrm{R}^{2}$ & 0.086 & 0.055 & 0.318 \\
Adjusted $\mathrm{R}^{2}$ & 0.050 & 0.018 & 0.296 \\
$p$-value & 0.031 & 0.189 & 0.001 \\
\hline
\end{tabular}

*Significant with Bonferroni adjusted critical value $(\mathrm{p}<0.017)$.

a Defined in an ordinal scale: 1. Less than 1 week; $2.1-2$ weeks; 3. 3-4 weeks; 4. 1- 2 months; 5 . >2 months.

${ }^{\mathrm{b}}$ Defined in an ordinal scale: $1 .<20 €$; to $9 .>200 €$.

${ }^{\mathrm{c}}$ Defined in a 7 point scale: 1 . Totally Unwilling to 7 . Totally Willing.

test the hypothesis of if serious surfing can influence surfing profile (Table 7 ). The results show that the six serious surfing qualities are good predictors of the surfing experience $\left(F_{(6}\right.$, ${ }_{162)}=6.043 ; p$-value $\left.=0.001\right)$, especially career $(\beta=0.180, \mathrm{t}(162)=2.401, p$-value $=0.016)$, effort $(\beta=-0.407, \mathrm{t}(162)=-5.566, p$-value $=$ $0.001)$ and identity $(\beta=-0.174, \mathrm{t}(162)=-2.406$, $p$-value $=0.016)$. Considering the positive $\beta$ value, higher valuation in the career quality corresponds to more years of surfing, while, considering the negative $\beta$ value, less effort and less identity valuation correspond to more years surfing.

The six serious surfing qualities are also good predictors of the surfing frequency $\left(F_{(6,162)}=\right.$
9.680; $p$-value $=0.001)$, specifically $\operatorname{career}(\beta=$ 0.349, $\mathrm{t}(162)=4.918, p$-value $=0.001)$, perseverance $(\beta=0.224, \mathrm{t}(162)=3.260, p$ value $=0.001)$ and effort $(\beta=-0.338, \mathrm{t}(162)=$ 4.869, $p$-value $=0.001)$. Considering the positive $\beta$ values, higher scores in career and perseverance corresponds to a higher surfing frequency. On the other hand, considering the negative $\beta$ value, to a less effort valuation corresponds to a more surfing frequency.

The role of serious surfing on surfing travel behaviour

Statistical testes indicated that the six serious surfing qualities are good predictors of surfing travel behaviour. Multiple linear regression (Table 8) indicates that the level of serious 
surfing shape their willingness to travel in the future $\left(F_{(6,193)}=14.970 ; p\right.$-value $\left.=0.001\right)$, especially Career $(\beta=0.526, \mathrm{t}(193)=8.876, p$ value $=0.001)$ and Ethos $(\beta=0.160, \mathrm{t}(193)=$ 2.693, $p$-value $=0.008$, which are positively correlated with the future intention to travel for surfing purposes. On the other hand, serious surfing qualities are not correlated with the length of surfing trips $\left(F_{(6,153)}=2.386\right.$; $p$-value $=$ $0.031)$ and the average spent per day $\left(F_{(6,153)}=\right.$ $1.478 ; p$-value $=0.189)$.

Binary logistic regressions tests (Table 9) also show that serious surfing qualities are good predictors of past surfing trips ( $p$-value $=0.001$ ) and future destinations ( $p$-value $=0.001)$ while for travelling companionship ( $p$-value $=0.480)$ and surfing destination choice ( $p$-value $=0.647)$ the models are not statistical significant. For career, higher values corresponds to more probability of have done one surfing trip in the past $\left(\beta=0.824 ; X^{2}\right.$ wald $(1)=18.890 ; p$-value $=$ $0.001)$ and more probability to travel for national destinations $\left(\beta=-0.364 ; x^{2}\right.$ wald $(1)=$ 5.518; $p$-value $=0.019)$; for effort, higher values corresponds to more probability of never made a surfing travel $\left(\beta=-0.383 ; X^{2}\right.$ wald $(1)=3.769$; $p$-value $=0.052$ ) and more probability to travel for international destinations $\left(\beta=0.524 ; x^{2}\right.$ wald $(1)=18.890 ; p$-value $=0.001)$; for identity,

Table 9. Binary logistic regressions of serious surfing on surf travel behaviour

\begin{tabular}{|c|c|c|c|c|}
\hline \multirow{2}{*}{$\begin{array}{l}\text { Independent } \\
\text { Variables: } \\
\text { Serious surfing } \\
\text { qualities }\end{array}$} & \multicolumn{4}{|c|}{$\begin{array}{l}\text { Dependent Variables } \\
\text { ( } \beta \text { and significance) }\end{array}$} \\
\hline & $\begin{array}{l}\text { Past surfing } \\
\text { trips }^{a}\end{array}$ & $\begin{array}{l}\text { Travelling } \\
\text { companionship }\end{array}$ & $\begin{array}{l}\text { Surfing } \\
\text { destinations } \\
\text { choice }^{c}\end{array}$ & Future destinations $^{d}$ \\
\hline Career & $0.824^{*}$ & -0.060 & 0.884 & $-0.364^{*}$ \\
\hline Ethos & -0.118 & -0.068 & -0.174 & 0.192 \\
\hline Perseverance & -0.055 & -0.265 & -0.308 & 0.063 \\
\hline Effort & $-0.383^{*}$ & 0.192 & -0.182 & $0.522^{*}$ \\
\hline Identity & -0.023 & -0.174 & 0.001 & $-0.287^{*}$ \\
\hline Benefits & $-0.415^{\star}$ & 0.235 & -0.149 & $-0.395^{\star}$ \\
\hline Constant & 1.645 & 1.047 & -3.000 & -0.940 \\
\hline Nagelkerke $\mathrm{R}^{2}$ & 0.222 & 0.049 & 0.066 & 0.154 \\
\hline$p$-value & 0.001 & 0.480 & 0.647 & 0.001 \\
\hline
\end{tabular}

${ }^{*} p \leq 0.1$

a Defined as done at least one surfing trip or never made a surfing travel.

${ }^{b}$ Defined as travelling accompanied or alone.

${ }^{\mathrm{c}}$ Defined as knowledge of the local or by specialists.

${ }^{\mathrm{d}}$ Defined as national or international destinations.

Table 10. Multiple linear regressions of serious surfing on surfing destination attributes

\begin{tabular}{|c|c|c|c|c|c|}
\hline \multirow[t]{2}{*}{ Independent Variables } & \multicolumn{5}{|c|}{$\begin{array}{c}\text { Dependent Variables } \\
\text { ( } \beta \text { and significance) }\end{array}$} \\
\hline & $\begin{array}{l}\text { Surfing } \\
\text { infrastructures } \\
\text { and cultural } \\
\text { ambience }\end{array}$ & $\begin{array}{l}\text { Hospitality } \\
\text { and touristic } \\
\text { facilities }\end{array}$ & $\begin{array}{l}\text { Surfing } \\
\text { natural } \\
\text { conditions }\end{array}$ & $\begin{array}{l}\text { No crowd } \\
\text { destination }\end{array}$ & $\begin{array}{l}\text { Natural } \\
\text { amenities }\end{array}$ \\
\hline Career & -0.015 & $0.434^{*}$ & $0.174^{*}$ & 0.089 & 0.011 \\
\hline Ethos & 0.036 & 0.124 & 0.040 & -0.048 & -0.100 \\
\hline Perseverance & -0.069 & -0.088 & 0.066 & 0.072 & $-0.211^{*}$ \\
\hline Effort & $0.371^{*}$ & $-0.278^{*}$ & 0.079 & -0.088 & -0.015 \\
\hline Identity & -0.016 & 0.016 & -0.071 & 0.093 & 0.067 \\
\hline Benefits & -0.114 & -0.003 & $0.195^{*}$ & 0.077 & 0.001 \\
\hline $\mathrm{R}^{2}$ & 0.157 & 0.289 & 0.086 & 0.038 & 0.059 \\
\hline Adjusted $\mathrm{R}^{2}$ & 0.131 & 0.267 & 0.057 & 0.008 & 0.030 \\
\hline$p$-value & 0.001 & 0.001 & 0.008 & 0.275 & 0.064 \\
\hline
\end{tabular}

${ }^{*}$ Significant with Bonferroni adjusted critical value $(p<0.017)$. 
higher values corresponds to more probability to travel for international destinations $(\beta=$ $0.287 ; x^{2}$ wald $(1)=2.707 ; p$-value $\left.=0.100\right)$; for benefits, higher values corresponds to more probability of never made a surfing travel $(\beta=$ $0.415 ; X^{2}$ wald $(1)=4.796 ; p$-value $\left.=0.029\right)$ and more probability to travel for international destinations $\left(\beta=-0.395 ; x^{2}\right.$ wald $(1)=5.658 ; p$ value $=0.017)$ and, finally; for ethos and perseverance qualities, no statistical differences were found in relation to past surfing trips and future destination variables.

Serious surfing related with surfing destination attributes preferences

Results show that the level of seriousness of respondents' shape their preferences for surfing destination attributes in surfing infrastructures and cultural ambience $\left(F_{(6,193)}=\right.$ $6.004 ; p$-value $=0.000)$, hospitality and touristic facilities $\left(F_{(6,193)}=13.062 ; p\right.$-value $\left.=0.001\right)$ and surfing natural conditions $\left(F_{(6,193)}=3.016 ; p\right.$ value $=0.008)$, while for no crowd destination $\left(F_{(6,193)}=1.275 ; p\right.$-value $\left.=0.275\right)$ and natural amenities $\left(F_{(6,193)}=2.026 ; p\right.$-value $\left.=0.064\right)$ the models are not statistically significant (Table 10).

Effort $(\beta=0.371, \mathrm{t}(193)=5.619, p$-value $=$ 0.001 ) is positively related with surfing infrastructures and cultural ambience; career $(\beta$ $=0.434, \mathrm{t}(193)=7.148, p$-value $=0.001)$ is positively related with hospitality and touristic facilities, while effort $\beta=0.278, \mathrm{t}(193)=4.574$, $p$-value $=0.001$ ) is negatively related with hospitality and touristic facilities. In the other hand, $\operatorname{career}(\beta=0.174, \mathrm{t}(193)=2.532, p$-value $=0.012)$ and benefits $(\beta=0.195, \mathrm{t}(193)=$ $2.837, p$-value $=0.005)$ are positively related with surfing natural conditions.

\section{Discussion and conclusions}

The results of this investigation allowed reinforcing the understanding of the serious leisure perspective as an important conceptual framework to study sport tourism participants (Melo, 2017). More specifically, this study contributes to the understanding of surf tourism, an important and emergent sport tourism sector in Portugal, by determining the surfers' socio-demographic characteristics, their surfing profile, surfing travel behaviour and surfing destination attributes.
Socio-demographic characteristics of responding surfers from this study is similar to other nature sports participants in Portugal (Melo \& Gomes, 2017), and to surfers reported in other studies from the literature (Barbieri \& Sotomayor, 2013; Dolnicar \& Flucker, 2003a). According to the results of this study, surfers in Portugal are mainly male, young/adult individuals with decreasing participation with the increase in age, with very high level of education, working for others, and with income above the Portuguese average. Respondents are also mostly experienced surfers with a frequent participation in surfing activities along the year, and with financial willingness to evolve in surfing. In this regard, the potential of the surfing activities is very attractive, given the high propensity of surfers to practice surfing activities along the year and their sociodemographic composition (with more educational qualifications and higher monthly incomes), which allow having more sustainable behaviours in the locals of their practices.

This study also highlights that surfers have a strong disposition for surf tourism, as already reported in the literature (Barbieri \& Sotomayor, 2013; Butts, 2001), because $80 \%$ of respondent surfers reported that they have already made a surf travel in the past, and the majority $(90 \%)$ have propensity to take a travel to surf in the future. This data, together with the average length of surfing trips and the average amount spent per day during the travel, allowed to reinforce that surf tourism is an increasing tourism sector able to generate an important economic impact.

Examination of the destination choice shows that the higher valued surfing destination attributes are related with surfing natural conditional (e.g., variety of places to surf and good waves quality), fact that can be explained because surfers are generally in constant quest for the perfect wave and surfing spots (Barbieri \& Sotomayor; Butts, 2001; Ponting, 2009; Ponting \& McDonald, 2013). On the other hand, surfing infrastructures and culture ambience (e.g., local surf schools/surf camps) are the less valued attributes probably because individuals of our sample are experienced surfers with autonomy (probably with their own equipment) that want to improve their skills and 
who do not need to purchase surfing services (e.g., equipment renting). Results of this study also show that, overall, the serious surfing items were classified with high scores $(M=5.320)$, as already reported in other studies (Barbieri \& Sotomayor, 2013), demonstrating that surfers present the six serious leisure qualities, especially related with benefits, career and identity. In turn, this allows reaffirming that surfing can be considered as a serious leisure activity.

Results of statistic tests indicated that the socio-demographic characteristics are not good predictors of serious surfing qualities as already mentioned in other studies (Barbieri \& Sotomayor, 2013). On the other hand, results show that the six serious surfing qualities are good predictors of the surfing profile, in surfing experience and surfing frequency. The positive correlation between career with surfing experience (number of years surfing) and surfing frequency, and between perseverance and surfing frequency demonstrates the high commitment need for surfers attain skills and knowledge to master the waves (Butts, 2001; Ponting, 2008) to achieve a (sense of) career progression. This data is important for surfing destinations with overall good natural conditions for surfing throughout the year (Portugal is a good example) as they can benefit from those conditions as a competitive advantage to capture frequent surfers who wanted to advance their skills. In turn, a negative correlation was found between effort with surfing experience and surfing frequency, and between identity with surfing experience, counteracting previous studies among surfers (Barbieri \& Sotomayor, 2013). These results should be interpreted with caution and can be explained by the fact that the more experienced surfers do not need to make a great effort (e.g., I'm willing to spend time and money in training for surfing techniques) because they already present those surfing techniques to master the waves, and they do not need to present (a perceived) higher identification with surfing (e.g., I believe no other leisure activities can replace surfing) than the less experienced surfers. On the other hand, for those who present higher perceived effort (e.g., I'm willing to purchase surfing books and video tapes to enhance my surfing techniques) the surfing frequency is lower, while for those who present less effort the surfing frequency is higher.

Contrariwise to other studies (Barbieri \& Sotomayor, 2013), results from this investigation show that the six serious surfing qualities are good predictors of surf travel behaviour, especially in past surfing trips, willingness to travel in the future, and future destinations. In this regard, career is a good estimator of past surfing trips, willingness to travel in the future, and future destinations; ethos is related to the willingness to travel in the future; effort is a good predictor of past surfing trips and future destinations; identity is related with future destinations and; benefits is also a good estimator of past surfing trips and future destinations. Moreover, results also show a correlation between seriousness of responding surfers and surfing destination attributes, in surfing infrastructures and cultural ambience, hospitality and touristic facilities and surfing natural conditions. Career is related with hospitality and touristic facilities and with surfing natural conditions; ethos is related with surfing infrastructures and cultural ambience and with hospitality and touristic facilities; effort is related with surfing infrastructures and cultural ambience, hospitality and touristic facilities and; benefits is related with surfing natural conditions. These results are able to give important information for the decision making process about where surfing activities should occur. Data related to the travel in the future and future destinations are important especially for those destinations that can offer high surfing natural conditions, allowing to attract those surfers who are expecting for high benefits and who want to progress in their surfing career.

This study also has some limitations, the first being the representativeness of the surfing population as a whole, because the data was collected by accidental sampling and an internet survey. The second limitation is the small size of the sample $(n=200)$ which, despite being sufficient to develop an exploratory study, presents some restrictions in terms of considering an applied methodology, because the number of dimensions in partitioning the task is extremely high. Additionally, it should be recognized that although the questionnaire was 
validated in two languages (Portuguese and English) problems appears for the nonPortuguese and the non-English native speakers. For these reasons, these results must be interpreted with caution, because participants do not represent the general perception of serious surfers; the results should be taken as indicative and hypothesisgenerating for further investigations. Future studies are necessary, with increased sample size, and using other sampling and data collecting methods which allow a higher representativeness of (national and international) individuals who surfs in Portugal, to further examine the influence of the seriousness of surfing across geographic regions. Furthermore, surf tourism should be investigated from other perspectives. For example, surfers' segmentation enables managers to decide which surfers groups are most attractive to them based on the strengths and resources of the respective destination, and determine which aspects of the destination product should be highlighted in promotion materials.

\section{References}

Barbieri, C. \& Sotomayor, S. (2013). Surf travel behavior and destination preferences: An application of the Serious Leisure Inventory and Measure. Tourism Management, 35, 111-121.

Bartram, S. (2001). Serious leisure careers among whitewater kayakers: A feminist perspective. World Leisure Journal, 43(2), 4-11.

Breedveld, J. (1995). Ripcurl Pro/Qui Womens Classic Surfing Contest economic impact assessment. Australian Leisure, 6(4), 15-16.

Buckley, R. (2002a). Surf tourism and sustainable development in Indo Pacific Island - the industry and the islands. Journal of Sustainable Tourism, 10(5), 405-424.

Buckley, R. (2002b). Surf tourism and sustainable development in Indo Pacific Island - recreational capacity management and case study. Journal of Sustainable Tourism, 10(5), 425-442.

Buckley, R. (2012). Rush as a key motivation in skilled adventure tourism: Resolving the risk recreation paradox. Tourism Management, 33, 961-970.
Butts, S. (2001). Good to the last drop: understanding surfers' motivations. Sociology of Sport Online, 4(1). Retrieved from: http://www.physed.otago.ac.nz/sosol /v4i1/v4i1butt.htm.

Campos, F., Portugal, A. \& Melo, R. (2017). Surf Tourism and Serious Leisure: a Comparison Between Less Serious and More Serious Surfers in Portugal. In R. Melo \& C. Sobry (Eds.), Sport Tourism: New Challenges in a Globalized World (pp. 299327). Cambridge: Cambridge Scholars Publishing.

Cheng, T. \& Tsaur, S. (2012). The relationship between serious leisure characteristics and recreation involvement: A case study of Taiwan's surfing activities. Leisure Studies, 31(1), 53-68.

Cole, J. \& Scott, D. (1999). Segmenting participation in wildlife watching: A comparison of casual wildlife watchers and serious birders. Human Dimensions of Wildlife, 4(4), 44-61.

Dilley, R. \& Scraton, S. (2010). Women, climbing and serious leisure. Leisure Studies, 29(2), 125-141.

Dolnicar, S. \& Fluker, M. (2003a). Behavioural market segments among surf tourists investigating past destination choice. Journal of Sport Tourism, 8(3), 186-196.

Dolnicar, S. \& Fluker, M. (2003b). Who's riding the wave? An investigation into demographic and psychographic characteristics of surf tourists. In Proceedings of the 13th international research conference of the Council for Australian University Tourism and Hospitality Education (CAUTHE).

Fluker, M. (2003). Riding the wave: defining surf tourism (Online). In Braithwaite, R. \& Braithwaite, R. (Eds.). CAUTHE 2003: Riding the wave of tourism and hospitality research (pp. 398-406). Lismore: Southern Cross University.

Getz, D. \& Fairley S. (2003). Media management at sport events for destination promotion: Case studies and concepts. Event Management, 8(3), 127-139.

Getz, D. \& McConnell, A. (2011). Serious sport tourism and event travel careers. Journal of Sport Management, 25, 326-339.

Gibson, H., Willming, C. \& Holdnak, A. (2002). "We're Gators. not just Gator fans": serious 
leisure and University of Florida football. Journal of Leisure Research, 34(4), 397425.

Gould, J. Moore, D., Karlin, N. Gaede, D., Walker, J. \& Dotterweich, A. (2011). Measuring serious leisure in chess: Model confirmation and method bias. Leisure Sciences, 33(4), 332-340.

Gould, J., Moore, D., McGuire, F. \& Stebbins, R. (2008). Development of the serious leisure inventory and measure. Journal of Leisure Research, 40(1), 47-68.

Hastings, D., Kurth, S., Schloder, M. \& Cyr, D. (1995). Reasons for participating in a serious leisure career: comparison of Canadian and U.S. masters swimmers. International Review for the Sociology of Sport, 30, 101-119.

Hill, M. \& Hill, A. (2002). Investigação por questionário. Lisboa: Sílabo.

Jones, I. (2000). A model of serious leisure identification: the case of football fandom. Leisure Studies, 19, 283-298.

Johnson, J. \& Orbach, M. (1986). The role of cultural context in the development of lowcapital ocean leisure activities. Leisure Sciences, 8(3), 319-339.

Kane, M. \& Zink, R. (2004). Package adventure tours: markers in serious leisure careers. Leisure Studies, 23(4), 329-345

Kelly, J. (1973). Surf parameters: Final report part II: Social and historical dimensions. Honolulu: University of Hawaii James K.K. Look Laboratory of Oceanographic Engineering.

Lazarow, N., Miller, M. \& Blackwell, B. (2008). The Value of Recreational Surfing to Society. Tourism in Marine Environments, 5(2-3), 145-158

Lee, S. \& Scott, D. (2013). Empirical linkages between serious leisure and recreational specialization. Human Dimensions of Wildlife, 18, 450-462.

Markrich, M. (1988). Economic Effects of Surfing Activities in Hawaii, UH Sea Grant College Program.

Maroco, J. (2011). Análise estatística com SPSS statistics. Pêro Pinheiro: ReportNumber.

Martin, S. \& Assenov, I. (2012). The genesis of a new body of sport tourism literature: A systematic review of surf tourism research
(1997-2011). Journal of Sport \& Tourism, 17(4), 257-287.

Martin, S. \& Assenov, I. (2014a). Developing a Surf Resource Sustainability Index as a Global Model for Surf Beach Conservation and Tourism Research. Asia Pacific Journal of Tourism Research, 19(7), 760-792.

Martin, S. \& Assenov, I. (2014b). Investigating the Importance of Surf Resource Sustainability Indicators: Stakeholder Perspectives for Surf Tourism Planning and Development. Tourism Planning \& Development, 11(2), 127-148.

Melo (2013). Desportos de Natureza e Desenvolvimento Local Sustentável: Análise dos Praticantes e das Organizações Promotoras dos Desportos de Natureza (Unpublished doctoral dissertation). University of Coimbra, Coimbra, Portugal.

Melo, R. (2017). Understanding Nature Sports Tourism Participation: A Literature Review. In R. Melo \& C. Sobry (Eds.), Sport Tourism: New Challenges in a Globalized World (pp. 241-275). Cambridge: Cambridge Scholars Publishing.

Melo, R. \& Gomes, R. (2017). Nature Sports Tourism Participation: Understanding Demand, Practice Profile, Motivations and Constraints. European Journal of Tourism Research, 16, 108-135.

Moutinho, L., Dionísio, P. \& Leal, C. (2007). Surf tribal behaviour: a sports marketing application. Marketing Intelligence \& Planning, 25(7), 668-690.

O'Connor, J. \& Brown. Y. (2010). Riding with the Sharks: Serious Leisure Cyclist's Perceptions of Sharing the Road with Motorists. Journal of Science and Medicine in Sport, 13, 53-58.

O'Brien, D. (2007). Points of leverage: Maximizing host community benefit from a regional surfing festival. European Sport Management Quarterly, 7(2), 141-165.

O'Brien, D. \& Ponting J. (2013). Sustainable Surf Tourism: A Community Centered Approach in Papua New Guinea. Journal of Sport Management, 27(2), 158-172.

Poizat-Newcomb, S. (1999a). The genesis of a sports tourism activity-surfing (part I). Journal of Sport \& Tourism, 5(4), 5-14

Poizat-Newcomb, S. (1999b) .The genesis of a sports tourism activity - surfing (part II). Journal of Sport \& Tourism, 5(4), 14-25. 
Ponting, J. (2008). Consuming Nirvana: An exploration of surfing tourist space (Unpublished doctoral dissertation). University of Technology, Sydney, Australia.

Ponting, J. (2009). Projecting paradise: the surf media and the hermeneutic circle in surfing tourism. Tourism Analysis, 14, 175-185.

Ponting, J. \& McDonald, M. (2013). Performance, agency and change in surfing tourist space. Annals of Tourism Research, 43, 415-434.

Ponting, J. \& O'Brien, D. (2014). Liberalizing Nirvana: an analysis of the consequences of common pool resource deregulation for the sustainability of Fiji's surf tourism industry, Journal of Sustainable Tourism, 22(3), 384402.

Reis, P. \& Jorge, J. (2012). Surf tourism: segmentation by motivation and destination choice. Proceedings of the 2nd International Conference on Tourism Recreation, Peniche.

Siegenthaler, K. \& O'Dell, I. (2003). Older golfers: Serious leisure and successful aging. World Leisure Journal, 45(1), 47-54.

Smith, S., Costello, C. \& Warren, J. (2010). Marathons as serious leisure tourism. In $\mathrm{J}$. Chen (Ed.), Advances in hospitality leisure (pp. 43-58). Bingley, Bradfors: Emerald Group Publishing Limited.

Spurgin, K. (2008). Everyday information organization practices in the pursuit of leisure: The information organization, management, and keeping activities of amateur art photographers. UNC Chapel Hill: School of Information and Library Science.
Stebbins, R. (1982). Serious leisure: a conceptual statement. The Pacific Sociological Review, 25(2), 251-272.

Stebbins, R. (1992). Amateurs, professionals, and serious leisure. Montreal: McGillQueen's University Press.

Stebbins, R. (1996a). Cultural tourism as serious leisure. Annals of Tourism Research, 23, 948-950.

Stebbins, R. (1996b). Volunteering: a serious leisure perspective. Nonprofit and Voluntary Sector Quarterly, 25, 211-224.

Stebbins, R. (2005). Challenging mountain nature: risk, motive and lifestyle in three hobbyist sports. Calgary: Detselig.

Stebbins, R. (2007). Serious leisure: A perspective for our time. New Brunswick: AldineTransaction.

Tsaur, S. \& Liang, Y. (2008). Serious leisure and recreation specialization. Leisure Sciences, 30(4), 325-341.

Tsung-Chiung, W. Chyong-Ru, L. \& Wan-Chen, Y. (2012). Segmenting indigenous tourists from a serious leisure perspective. Journal of Vacation Marketing, 18(1), 117-129.

Wheaton, B. (2010). Introducing the consumption and representation of lifestyle sports. Sport in Society, 13(7-8), 1057-1081.

Yoder, D. (1997). A model for commodity intensive serious leisure. Journal of Leisure Research, 29(4), 407-429. 